\section{CeRVICAL CANCER SCREENING: BARRIERS TO ACCESS AND POTENTIAL SOLUTIONS FOR NIGERIA}

\author{
Christie Divine Akwaowo', Tazio Vanni²
}

\begin{abstract}
In developed countries, giant strides have been made in reducing mortality due to cervical cancer. The success recorded has been largely attributed to effective screening programmes. In contrast, the burden and mortality due to this disease is rising in developing countries. Access to screening services remains a major challenge for the majority of the population at risk. This paper reviews the current demand-side barriers to cervical cancer screening in Nigeria and identifies potential solutions. Using academic databases and grey literature, a review was carried out to identify current screening modalities, barriers to access, and potential solutions. The current innovative method for control is early detection and treatment using "See and Treat" which involves visual inspection of the cervix with acetic acid (VIA) and cryotherapy. Lack of awareness, cost, and availability were identified as major barriers to access. Potential solutions feasible in the Nigerian context were categorized as financial and non-financial. The potential financial interventions include voucher schemes, conditional cash transfers, health equity, community loan funds, and prepayment mechanisms. Potential non-financial interventions that would be useful include raising awareness via health education and counseling, community participation, community based interventions, and pre-payment mechanisms.
\end{abstract}

Keywords: Cervical cancer; cancer screening; demand; developing countries; access

The misconception that cancer is a disease that can only be diagnosed and treated in specialist care facilities is fast shifting grounds with the increasing recognition that primary care has a role in all stages of the cancer control and care continuum ${ }^{1}$. The cancer transition, which is a part of the ongoing epidemiologic transition faced by developing countries, is projected to lead to a $75 \%$ increase in cancer incidence in the low and middle income countries (LMICs) between the year 2000 and $2020^{2}$. This has created the double burden of cancer, a challenge for governments who are faced with the task of deciding which interventions to allocate scarce resources.

Cervical cancer is a preventable malignancy, yet it is the second leading cause of cancer deaths in women worldwide. An estimated 266,000 deaths from cervical cancer occurred worldwide in 2012 , accounting for $7.5 \%$ of all female cancer deaths ${ }^{3}$, with nearly $90 \%$ of these deaths occurring in low- and middle-income countries (LMICs) ${ }^{4}$. The disproportionate burden of cervical cancer in the LMICs gives a dismal picture of 53,300 deaths in Africa, compared to the high-income countries (HICs) where the mortality rates from this disease is declining ${ }^{2}$. The decline has been attributed to successful cervical cancer screening cytology programmes, which have been integrated as a routine part of preventive care in these countries ${ }^{5}$.

In Sub Saharan Africa, where women are the main income earners in onethird of households, the economic burden is magnified by the loss of the main income earner, besides the pain and suffering imposed by the disease. ${ }^{6}$ The affected families often suffer economic loses imposed by illness and premature death. This loss is incurred not only as a result of loss of earnings, but also due to the out-of-pocket expenditure required for treatment of this condition. This
Clin Biomed Res. 2015;35(1):5-13

1 Institute of Health Research, University of Uyo Teaching Hospital Uyo, Uyo, Akwa Ibom State, Nigeria.

2 Ministério da Saúde, Brasília, DF, Brazil.

Corresponding author:

Christie Divine Akwaowo

E-mail: christie.d.akwaowo@gmail.com

Institute of Health Research, University of Uyo Teaching Hospital Uyo

Community Health Department, University of Uyo. Uyo, Akwa Ibom State, Nigeria. 
can lead to catastrophic expenditure, undermining financial protection at the household level.

There is a paradigm shift in cancer care and control with increasing recognition that cancer can be managed at all levels of care, especially at the $\mathrm{PHC}$ level which is closest to the community. This is particularly pertinent with the increasing reliance of the health systems on hospitals and specialists, tagged "hospital-centrism", which has greatly undermined the core values of PHC creating a major source of inefficiency and inequality ${ }^{7}$. As efforts are made to expand universal health coverage (UHC) in the LMICs, equity in access to cervical cancer screening is an important issue especially in Sub-Saharan Africa, where poverty is widespread. It is advocated that cervical cancer screening be integrated into already existing programs, such as family planning and maternal and child health programs using the diagonal approach to achieve health system strengthening ${ }^{8}$. The Pink Ribbon/Red Ribbon Initiative advocates the integration of breast and cervical cancer screening into existing HIVIAIDS programs at primary care level ${ }^{9}$. However, the stigma associated with HIV programs and the fact that this will lead to the exclusion of a large group of women reiterate the equity issues in cervical cancer screening.

Screening is defined as population testing to identify early disease or precursors of a disease in asymptomatic individuals. It could be targeted at the entire population (mass screening) or at individuals (selective screening). The WHO criteria as drawn up by Wilson and Jungner sets the framework against which screening can be judged as appropriate for any condition ${ }^{10}$. Judged against these criteria, cervical cancer screening presents an excellent opportunity for this otherwise fatal condition to be cured by early detection and treatment, thus reducing morbidity and mortality from this disease. Prevention of cervical cancer involves primary screening by vaccination with the HPV vaccine and secondary screening involves the use of cytology and other innovative methods as discussed subsequently ${ }^{11,12}$.

\section{The Challenge of Cervical Cancer Screening in Low and Middle Income Countries}

Many HICs have successfully instituted and sustained mass-organised cytology-based screening programs, however this remains a challenge for LMICs (due to lack of the required infrastructural requirements, both human and material, to support cytology-based programs $)^{13}$. Replicating the success of cervical cancer screening in the LMICs has been difficult, leading to low coverage. In a study of 57 countries on the coverage of cervical cancer screening, an average of $19 \%$ was reported, compared to $63 \%$ in developed countries, ranging from $1 \%$ in Bangladesh to $73 \%$ in Brazil ${ }^{5}$.

The failure to successfully replicate the PAP smear cytology in LMICs has led to the evaluation and adoption of alternative innovative approaches to ensure sustainability of prevention programmes. These include techniques for testing and treatment of precancerous lesions in a single visit, using "direct visualization" (either visualization with coloration with acetic acid [VIA] or with Lugol's iodine [VILI]). These techniques have been piloted in trials in LMICs, with positive results ${ }^{14}$. The treatment (for women without advanced disease) is by cryotherapy - freezing of abnormal tissue.

Many studies have evaluated the cost-effectiveness of the different health technologies available for cervical cancer screening in low-resource settings ${ }^{15-17}$. However, not many studies have focused on access to these screening mechanisms and how the health system financing mechanism may actually affect the uptake of cervical cancer screening.

This paper attempts to address this gap in knowledge by reviewing the barriers to access and potential solutions to demand-side barriers to access to cervical cancer screening in Nigeria. First, an overview of the challenges to screening in LMICs and the current options available are outlined. This is followed by a review of barriers to access and potential solutions. Finally, a discussion of the findings and the policy implications of integrating cervical cancer care in Nigeria's health system are highlighted.

\section{METHODS}

To answer the research questions, a mixed research employing a systematic literature review was carried out in stages as follows:

A literature review was done systematically. Words describing the dimensions of access including affordability, availability acceptability, and awareness were keyed in as synonyms of access and synonyms of developing countries were also used. Academic databases used included EMBASE, Global Health, and MEDLINE, Social Policy and Practice, Health Management Consortium, and Econlit.

Additionally, manual search for the literature not available was done by tracing references and snowballing. Non-journal and grey literature were used in order to ensure a more complete search and to access literature not available on the academic databases listed above.

The search engines used included Scirus, ELDIS, and Google (and Google Scholar). Additionally, Internet websites of organizations involved in cancer control 
policies were searched, including the World Health Organization (WHO), and the International Agency for Research on Cancer (IARC).

\section{Inclusion Criteria}

Any study was included in this review, if:

- The study was performed in developing countries

- The study was published in English

- The study focused on screening

\section{Exclusion Criteria}

Any study was excluded if

- The study was done in developed country

- Published in a language other than English

- Published before January 1, 1990

Manual search for literature that was not available was done by tracing references and snowballing. Non-journal and grey literature was used in order to ensure a more complete search and to access literature that was not available on the academic databases listed above. All references from the search engines were downloaded into the Endnotes Reference Manager.

Although the study originally set out to explore both demand- and supply-side barriers to access and possible interventions, the research had to be modified to demand-side barriers and interventions due to time and space limits. The search was carried out on the different interventions to address these barriers though not discussed in detail due to space and time limits. The key themes of the papers reviewed were categorized into demand- and supply-side barriers and were discussed along these lines, using the dimensions of access as described by Peters et al ${ }^{18}$.

\section{RESULTS}

\section{Options for Cervical Cancer Screening}

There are various methods available for screening for cervical cancers in LMICs. Such options include:

1. Cytology: This is the traditional method of screening using Pap smear. The test involves scraping and fixing cervical cells on a slide, which is then analyzed by a trained pathologist or technician to determine the presence of any abnormal cells. However, the unavailability of infrastructural requirements, both human and material, to support cytology-based programs and the time taken for results to be available make this an impractical and inefficient option in most low-resource settings ${ }^{13}$.
2. Visual inspection with acetic Acid (VIA): This involves naked-eye inspection of the cervix under bright light conditions at least $1 \mathrm{~min}$ after the application of $3.5 \%$ diluted acetic acid. The test can be carried out by nurses or midwives, who check for aceto-white areas in the uterine cervix. Several studies documenting the efficacy of these options for screening have been published ${ }^{11,19}$. Variants of this include:

2.1 VIA with low-level magnification (VIAM): the magnification of (2.4X) using a hand-held device is utilized to inspect the cervix. There is, however, no evidence that this procedure improves the performance of the naked-eye visualization test ${ }^{14}$.

2.2 VIA with Lugol's lodine (VILI): visual inspection using Lugol's iodine solution that stains glycogen stored in cervical epithelial cells. The yellow-coloured changes associated with a positive VILI test result are recognized more easily by health workers than the acetowhite changes associated with VIA. In a large multicentre trial involving almost 50,000 women, Sankaranarayanan et al. reported a higher sensitivity with the VILI compared to VIA, varying from $78 \%$ to $98 \%$ and specificity varying from $73 \%$ to $91 \%{ }^{14}$. These data suggest that VILI is a more sensitive test than VIA.

3. HPV/DNA testing: This method has been found to be more objective, preventing more deaths in advanced disease and deaths compared with the Pap Smear or VIA testing. Evidence comes from several studies including a large randomized control trial (RCT) carried out in rural India ${ }^{20}$. The self-sampling method, despite reducing sensitivity, has been found to be more effective.

"See and treat" or refer, integrating either of the VIA or its variants or the HPV with immediate cryotherapy or LEEP is referred to as the "see-and-treat" approach. Integration of the see-and treat with the HPV testing programs offers the dual benefits of HPV screening to maximize detection and using VIA to triage for advanced lesions/cancer, as well as a pelvic exam to address other gynaecologic issues ${ }^{11}$. In an urban-based trial in Ghana, a single visit approach was found to be efficient, safe and feasible ${ }^{21}$. A comparison of the options available for screening is shown in Table 1.

\section{Barriers to Access}

There is no universally accepted definition of access to health services and utilization is used as a proxy for access in most literature ${ }^{22}$. However, as noted by Peter et al., most authors define access as 'the timely use of service according to need', since most definitions would incorporate the idea of realized 
Table 1: A comparison of the options for Cervical Cancer Screening in LMICs.

\begin{tabular}{|c|c|c|c|}
\hline $\begin{array}{l}\text { Operational } \\
\text { aspect }\end{array}$ & Pap Smear & VIA/VILI & $\begin{array}{l}\text { Low-cost } \\
\text { HPV tests }\end{array}$ \\
\hline $\begin{array}{l}\text { Cost per } \\
\text { test }\end{array}$ & $\begin{array}{l}\text { Moderate to high } \\
(\$ 10-\$ 25)\end{array}$ & $\operatorname{Low}(<\$ 5)$ & $\operatorname{Low}(<\$ 8)$ \\
\hline Provider & $\begin{array}{l}\text { Cytotechnologists/ } \\
\text { cyto- technicians }\end{array}$ & $\begin{array}{l}\text { Nurses/ } \\
\text { midlevel } \\
\text { workers }\end{array}$ & $\begin{array}{c}\text { Lab } \\
\text { technicians }\end{array}$ \\
\hline $\begin{array}{l}\text { Sensitivity } \\
\text { of single } \\
\text { test }\end{array}$ & $60-80 \%$ & $50-80 \%$ & $80-95 \%$ \\
\hline $\begin{array}{l}\text { Specificity } \\
\text { of single } \\
\text { test }\end{array}$ & $85-95 \%$ & $70-80 \%$ & $50-70 \%$ \\
\hline $\begin{array}{l}\text { Minimum } \\
\text { number of } \\
\text { visits }\end{array}$ & 2 & 1 & 1 \\
\hline $\begin{array}{l}\text { Linking } \\
\text { screening } \\
\text { and } \\
\text { treatment }\end{array}$ & $\begin{array}{l}\text { Not possible in } \\
\text { same visit }\end{array}$ & $\begin{array}{c}\text { Possible in } \\
\text { same visit } \\
\text { "See \& } \\
\text { Treat" }\end{array}$ & $\begin{array}{l}\text { Possible } \\
\text { in same } \\
\text { visit }\end{array}$ \\
\hline $\begin{array}{l}\text { Training } \\
\text { requirements }\end{array}$ & Substantial & $\begin{array}{c}\text { Relatively } \\
\text { modest }\end{array}$ & $\begin{array}{c}\text { Relatively } \\
\text { modest }\end{array}$ \\
\hline $\begin{array}{l}\text { Quality } \\
\text { assurance }\end{array}$ & Substantial & $\begin{array}{c}\text { Significant } \\
\text { need to } \\
\text { ensure }\end{array}$ & $\begin{array}{l}\text { Minimal } \\
\text { need }\end{array}$ \\
\hline
\end{tabular}

Adapted from Sahasrhabudde ${ }^{11}$.

Table 2: Dimensions of Access.

Geographical The physical distance or travel time Accessibility from service delivery point to the user

Availability Having the right type of care available to those who need it

Affordability The relationship between the price or Financial of services (in part affected by their Accessibility costs) and the willingness and ability of users to pay for those services, as well as be protected from the economic consequences of health costs

Acceptability The match between how responsive health service providers are to the social and cultural expectations of individual users and communities

need $^{18}$. The framework for discussing dimensions of access as described by Peters is shown in Table 2.

In this paper, these barriers to access have been categorized into demand-side and supply-side barriers $^{23}$. However, though described separately, access barriers are not mutually exclusive and often interact ${ }^{24}$. Demand-side determinants are factors influencing the ability to use health services at individual, household, or community level, while supply-side determinants are aspects inherent to the health system that hinder service uptake by individuals, households or the community ${ }^{23}$.

A summary of both demand- and supply-side barriers identified is presented in Table 3 .

\section{Availability}

This is in terms of both human resources and the materials required for screening. The majority of healthcare workers, though aware, do not recommend screening ${ }^{25}$.

However, by far the greatest challenge to screening in Nigeria was identified as lack of awareness ${ }^{26}$. This was both a supply- and demand-side barrier as both the healthcare workers and the service users showed a lack of awareness. This is similar to other studies in other LMICs which document low levels of awareness among women ${ }^{27}$.

As with uptake of most health services, educational status is significantly related with uptake of screening ${ }^{28}$. Women with low educational status were less likely to use the services ${ }^{29}$.

\section{Acceptability}

Fear of abnormal results, fatalism (Gods will), inappropriate beliefs, fear from cancer diagnosis and pain related to the procedure were all cited as barriers to screening. Qualitative studies highlighted the strong socio-cultural context especially in the north, where women have to seek permission from their husbands before making healthcare decisions ${ }^{30}$.

Stigma and personal embarrassment is also another identified barrier often associated with socio-cultural factors, and screening misconceptions affiliated with HIV screening ${ }^{31}$. Availability of a female health worker was also cited as most women are embarrassed at being examined by a male $\mathrm{HCW}$, besides many men would not want their wives examined by a male ${ }^{26,32}$.

\section{Geographical Accessibility}

The geographical location of the centre where screening is offered determines the uptake of services. Where services are urban-based, more women access these services and the rural women lack access $^{33}$. Service location and household location relate to distance from the household to the place of service delivery. Geographical access barriers can also undermine equity in health services utilization; people further away from health facilities are less likely to access services and have lower utilization rates ${ }^{34}$.

\section{Affordability}

One of the major barriers to uptake is costs of service and lack of finances, an important factor, as a 
Table 3: Demand- and Supply-Side Barriers to Access.

\begin{tabular}{ll}
\hline \multicolumn{1}{c}{ Supply-side barriers } & \multicolumn{1}{c}{ Demand-side barriers } \\
\hline Geographical accessibility & • Indirect costs to household \\
- Service location & - Transportation \\
Far/ urban based & • Awareness \\
$\begin{array}{l}\text { Availability } \\
\text { - Unskilled health workers }\end{array}$ & • Education \\
- Health worker awareness/offering service & - Waiting times \\
- No equipment /consumable & \\
- Non-integration of health services & \\
- Lack of opportunity (exclusion from services) & \\
- Late or no referral & • Household resources and willingness to pay \\
Affordability & - Opportunity costs \\
- Costs and prices of services, including informal & - Cash flow within society \\
payments & \\
- Private-public dual practices & - Community and cultural preferences \\
Acceptability & - Stigma \\
- Staff interpersonal skills, including trust & - Lack of health awareness \\
- Availability of female HCW & - Sociocultural Factors \\
\hline
\end{tabular}

significant part of the total cost of accessing services falls on the demand side ${ }^{25,27,35}$. The various dimensions to accessing health services are summarized in the data from the Nigerian National Demographic Health Survey $2009^{6}$. This covers acceptability, affordability, geographical, and availability issues.

\section{Potential Solutions for Addressing the Demand Side Barriers}

To ensure improved access to healthcare interventions, especially for the poor and vulnerable, the barriers on both supply and demand sides have to be addressed ${ }^{36}$. An overview of the available interventions to address these barriers using the framework adapted from Jacobs et al. is shown in Table 4. The various mechanisms that could be used have been categorized into financial and non-financial interventions and discussed under along the dimensions of access. The financial schemes address the dimensions of affordability and geographical access, which tend to be related, while the non-financial schemes address awareness and acceptability barriers ${ }^{37}$.

\section{Financial Interventions}

Demand-side financial interventions include voucher schemes, conditional cash transfers, health equity and community-loan funds, and prepayment mechanisms ${ }^{38}$. Health vouchers can be used to encourage the use of under-consumed services like family planning, treatment of infectious diseases, and maternal and child health services by subsidizing (fully or partially) healthcare costs ${ }^{39}$. They are different from health equity funds, which are third-party mechanisms that
Table 4: Financial and Non-financial Interventions to address demand-side barriers to uptake of cervical cancer screening.

\begin{tabular}{|c|c|c|}
\hline \multirow[t]{2}{*}{ Barrier } & \multicolumn{2}{|c|}{ Interventions } \\
\hline & Financial & Non-financial \\
\hline Awareness & & $\begin{array}{l}\text { Raising } \\
\text { awareness: } \\
\text { use of mass } \\
\text { media/IEC in the } \\
\text { dialects } \\
\text { Social marketing/ } \\
\text { franchising }\end{array}$ \\
\hline Acceptability & & $\begin{array}{l}\text { Community } \\
\text { participation } \\
\text { Community- } \\
\text { based } \\
\text { interventions }\end{array}$ \\
\hline $\begin{array}{l}\text { Geographical } \\
\text { access }\end{array}$ & $\begin{array}{l}\text { Vouchers } \\
\text { Community- } \\
\text { loan funds for } \\
\text { transportation } \\
\text { Health subsidies for } \\
\text { the poor }\end{array}$ & \\
\hline Affordability & $\begin{array}{l}\text { Conditional cash } \\
\text { transfers } \\
\text { Voucher schemes } \\
\text { Health equity funds } \\
\text { Prepayment } \\
\text { schemes } \\
\text { (Community-Based } \\
\text { Health Insurance) }\end{array}$ & \\
\hline
\end{tabular}

Adapted from Peters et $\mathrm{al}^{18}$.

reimburse selected health care providers for services delivered to eligible poor.

Conditional cash transfers are monetary transfers made to households over a certain time period when 
complying with certain health behaviour ${ }^{40}$. Thus they can make money available for transport while cash transfers make money available for transport (geographic accessibility), often deal with low education (availability), address household resources and cash flow within society (affordability), specifically deal with health awareness, and can tackle low self-esteem, cultural preferences, and stigma (acceptability) ${ }^{37}$.

Finally, the pre-payment mechanisms spread the risk of health costs. However, while social health insurance covers only formal-sector salaried workers, community-based health insurance for the informal sector tends to be non-inclusive of the poor ${ }^{34}$. The evidence is mixed that community-based health insurance improves access to health services. This has been documented in systematic reviews, observational studies and quantitative studies ${ }^{34,41}$. There is evidence however, that with appropriately designed schemes - including strong participatory processes, targeted subsidies, facilitation of contribution payments, ensuring that services are delivered at facilities close to where people live, and effective information campaigns - the poorest can be included and geographical access barriers minimized ${ }^{34}$.

\section{Non-financial Interventions}

The non-financial interventions which would be useful for cervical cancer screening include raising awareness, community participation, and community-based interventions ${ }^{37,42}$. Raising awareness would involve the use of counselling and provision of consumer information on service. This has been found to be effective as seen in Bangladesh's schemes. The use of multimedia has been shown to be effective in creating awareness as shown in a study in Lagos ${ }^{43,44}$.

Community-based interventions which can be implemented by non-professional health workers, can be used to address issues related to service location, transport-associated costs and means (geographical accessibility), costs of service (affordability), and treatment availability ${ }^{45}$. As these non-professional health workers are recruited from within the community, many acceptability barriers are reduced for health interventions they promote, although the range of health interventions that they deliver is limited ${ }^{42}$.

While supply-side financing aims at strengthening the health sector, demand-side financing is directed linked to the subsidy, the beneficiary, and the objective of the subsidy, leading to improved care-seeking behaviour ${ }^{46}$.

\section{DISCUSSION}

The barriers to accessing cervical cancer screening in Nigeria reflect the gaps in knowledge by the service users, the market failure and informational asymmetry that characterize the healthcare sector. The challenges of screening are similar to that seen in other LMIC countries. There are various innovative technologies for screening identified including combination of vaccination, screening and see-and-treat. However, increasing access to cervical cancer screening requires addressing structural barriers related to the health system and poverty. The barriers to accessing cervical cancer screening resonates the perennial barriers to accessing health care services in Nigeria. As seen in Figure 1, the biggest barrier to accessing health services is financial (55\%), distance to health facility $(37 \%)$ and having to take transport $(30 \%)^{6}$. This makes a strong case for reducing financial barriers to accessing health care an imperative for the rural poor in Nigeria. These cost issues raise a dire need for cervical cancer screening to be made available without direct out-of-pocket expenditure which leads to substantial health care expenditure for the majority of Nigerians.

The cost to households of seeking care, including user fees, transportation and lost labour time, is a significant factor in health care decisions ${ }^{24}$. This is worse in a situation where there is no apparent ill health and people therefore see no reason to visit the health care facility.

A potential financial mechanism to improve access to screening is the use of vouchers. These have been used in Uganda, Pakistan, and India ${ }^{47}$. The majority of these schemes used targeted mechanisms to deliver subsidies to individuals, who in the absence of the subsidy would likely not have sought care. In all programs a positive behavioral response was observed, with providers investing voucher revenue to attract more clients and improved uptake of services documented.

To address the low levels of awareness, counselling and provision of consumer information on health services, including their availability, intention, and associated costs could be used. The use of news

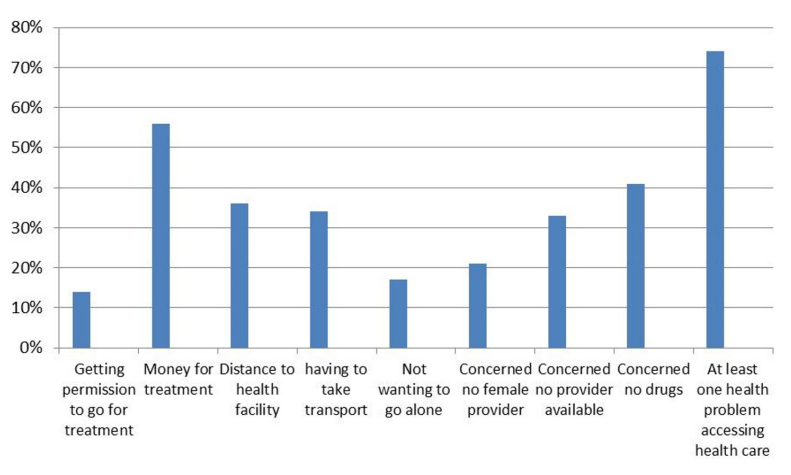

Figure 1: Barriers to accessing health care services by Nigerian families. Adapted from NDHS $2008^{6}$. 
and electronic media and the internet could serve to address acceptability barriers as the expectations and needs are tackled.

However, of the potential interventions to addressing these barriers, community participation and communitybased interventions and pre-payment mechanisms serves as the most versatile mechanisms, offering crosscutting interventions that address all the four dimensions of access. By helping reduce transport costs, improved information about services as well as health aspects, reducing opportunity costs, they enable access to sufficient cash within the community when needed, while addressing household expectations and community and cultural preferences ${ }^{48}$.

\section{Policy Recommendations}

Community-based Health Insurance, a form of pre-payment mechanism provides one of the most feasible means of addressing all four dimensions of access. It can reduce exposure to information asymmetry (i.e., that they are aware of the benefits but the clients are not) by investing in beneficiary awareness and education, through control of the benefit package (i.e., preparing comprehensive packages incorporating cancer screening), and in their role as negotiators with health care providers over prices of services.

The establishment of functional regional cancer registries in the six geopolitical regions to feed into the national database will facilitate screening while ensuring coverage.

To meet the increased demand from raised awareness and the Community-based Health Insurance, the mid-level workers, healthcare workers, CHEWs currently available in all the states could be utilized. Training this category of workers in VIA "See and Treat" will lead to task shifting of clinical skills. The two-way referral system advocated has not been utilized. It would be worth trying a shared management where these first level health care workers would see and then refer to the higher-level facility to strengthen the $\mathrm{PHC}$ referral systems. This will ensure prompt management of cases beyond the scope of the mid-level workers.

\section{Conflicts of interest}

The authors declare no conflicts of interest.

\section{REFERENCES}

1. Kringos DS, Boerma WG, Hutchinson A, van der Zee J, Groenewegen PP. The breadth of primary care: a systematic literature review of its core dimensions. BMC Health Serv Res. 2010;10(1):65. http://dx.doi. org/10.1186/1472-6963-10-65. PMid:20226084

2. Ferlay J, Shin HR, Bray F, Forman D, Mathers C, Parkin DM. Estimates of worldwide burden of cancer in 2008: GLOBOCAN 2008. Int J Cancer. 2010;127(12):2893-917. http://dx.doi.org/10.1002/ijc.25516. PMid:21351269

3. International Agency for Research on Cancer (IARC). Cervical cancer estimated incidence, mortality and prevalence worldwide in 2012. Lyon: WHO: IARC; 2012. [cited 2014 Oct 27]. Available from: http://globocan. iarc.fr/old/FactSheets/cancers/cervixnew.asp.

4. Bray F, Ren JS, Masuyer E, Ferlay J. Global estimates of cancer prevalence for 27 sites in the adult population in 2008. Int J Cancer. 2013;132(5):113345. http://dx.doi.org/10.1002/ijc.27711.

5. Gakidou E, Nordhagen S, Obermeyer Z. Coverage of cervical cancer screening in 57 countries: low average levels and large inequalities. PLoS Med [Internet] 2008 June 17 [cited 2012 July 11];5(6):e132. Available from: URL: http://www.ncbi.nlm.nih. gov/pubmed/18563963.

6. National Population Commission (NPC), ICF Macro. Demographic and Health Survey 2008. Abuja: National Population Commission; Calverton: ICF Macro;2009.

7. World Health Organization (WHO). World Health Report 2008, PHC-Now more than ever. Geneva: WHO; 2008.

8. Ooms G, Van Damme W, Baker B, Zeitz P, Schrecker T. The 'diagonal' approach to Global Fund financing: a cure for the broader malaise of health systems? Global Health. 2008;4(1):6. http://dx.doi.org/10.1186/1744-86034-6.

9. Institute TGWB. The George W. Bush Institute announces new women's health initiative Dallas, TX.The George W. Bush Presidential Center; 2011 [cited 2012 Aug 15]. Available from: http://www.bushcenter.org/ press-releases/2012/09/14/georgew-bush-institute-announces-newwomen $\%$ E2\%80\%99s-health-initiative.
10. Wilson JMG, Jungner G, World Health Organization (WHO). Principles and practice of screening for disease. Geneva: World Health Organization; 1968. Public Health Papers, no. 34.

11. Sahasrabuddhe VV, Parham GP, Mwanahamuntu $\mathrm{MH}$, Vermund $\mathrm{SH}$. Cervical cancer prevention in low- and middle-income countries: feasible, affordable, essential. Cancer Prev Res (Phila). 2012;5(1):11-7. http://dx.doi. org/10.1158/1940-6207.CAPR-110540. PMid:22158053

12. World Health Organizatio (WHO). Comprehensive cervical cancer control: a guide to essential practice. Geneva: WHO; 2006. Integrating Health Care for Sexual and Reproductive Health and Chronic Diseases.

13. Parham GP, Mwanahamuntu MH, Pfaendler KS, Sahasrabuddhe VV, Myung D, Mkumba G, et al. eC3--a modern telecommunications matrix for cervical cancer prevention in Zambia. J Low Genit Tract Dis. 2010;14(3):167-73. http://dx.doi. org/10.1097/LGT.0b013e3181cd6d5e.

14. Sankaranarayanan $R$, Basu $P$, Wesley RS, Mahe C, Keita N, Mbalawa CCG, 
IARC Multicentre Study Group on Cervical Cancer Early Detection, et al. Accuracy of visual screening for cervical neoplasia: results from an IARC multicentre study in India and Africa. Int J Cancer. 2004;110(6):90713. PMid: 15170675

15. Ginsberg GM, Edejer TT, Lauer JA, Sepulveda C. Screening, prevention and treatment of cervical cancer - a global and regional generalized cost-effectiveness analysis. Vaccine. 2009;27(43):6060-79. http://dx.doi. org/10.1016/j.vaccine.2009.07.026. PMid:19647813

16. Vanni T, Luz PM, Grinsztejn B, Veloso VG, Foss A, Mesa-Frias M, et al. Cervical cancer screening among HIV-infected women: an economic evaluation in a middle-income country. Int J Cancer. 2012;131(2):E96-104. http://dx.doi.org/10.1002/ijc.26472. PMid:21964797

17. Muñoz N, Franco EL, Herrero R, Andrus JK, Quadros C, Goldie $\mathrm{SJ}$, et al. Recommendations for cervical cancer prevention in Latin America and the Caribbean. Vaccine. 2008;26(Suppl 11):L96107. http://dx.doi.org/10.1016/j. vaccine.2008.05.062. PMid:18945407

18. Peters DH, Garg A, Bloom G, Walker DG, Brieger WR, Rahman MH. Poverty and access to health care in developing countries. Ann N Y Acad Sci. 2008;1136(1):161-71. http:// dx.doi.org/10.1196/annals.1425.011. PMid:17954679

19. Ngoma T, Muwonge R, Mwaiselage J, Kawegere J, Bukori P, Sankaranarayanan R. Evaluation of cervical visual inspection screening in Dar es Salaam, Tanzania. International Journal of Gynecology \&amp. Obstetrics. 2010;109(2):100-4

20. Sankaranarayanan R, Esmy PO, Rajkumar R, Muwonge R, Swaminathan $R$, Shanthakumari $S$, et al. Effect of visual screening on cervical cancer incidence and mortality in Tamil Nadu, India: a cluster-randomised trial. Lancet. 2007;370(9585):398-406. http://dx.doi. org/10.1016/S0140-6736(07)61195-7. PMid:17679017

21. Blumenthal PDMDMPH, Gaffikin LD, Deganus SMBC, Lewis RMPH, Emerson MMA, Adadevoh SMD, et al. Cervical cancer prevention: safety, acceptability, and feasibility of a single-visit approach in Accra, Ghana. Am J Obstet Gynecol. 2007;196(4):407e1-e9. http://dx.doi. org/10.1016/j.ajog.2006.12.031.

22. Oliver A, Mossialos E. Equity of access to health care: outlining the foundations for action. $J$ Epidemiol Community Health. 2004;58(8):6558. http://dx.doi.org/10.1136/ jech.2003.017731. PMid:15252067

23. Ensor T, Cooper S. Overcoming barriers to health service access: influencing the demand side. Health Policy Plan. 2004;19(2):69-79. http:// dx.doi.org/10.1093/heapol/czh009. PMid:14982885

24. James CD, Hanson K, McPake B, Balabanova D, Gwatkin D, Hopwood I, et al. To retain or remove user fees?: reflections on the current debate in low- and middle-income countries. Appl Health Econ Health Policy. 2006;5(3):137-53. http://dx.doi. org/10.2165/00148365-20060503000001. PMid:17132029

25. Dim CC, Ekwe E, Madubuko T, Dim NR, Ezegwui HU. Improved awareness of Pap smear may not affect its use in Nigeria: a case study of female medical practitioners in Enugu, southeastern Nigeria. Trans $R$ Soc Trop Med Hyg. 2009;103(8):8524. http://dx.doi.org/10.1016/j. trstmh.2009.03.020. PMid:19394990

26. Ezem BU. Awareness and uptake of cervical cancer screening in Owerri, South-Eastern Nigeria. Ann Afr Med. 2007;6(3):94-8. http://dx.doi. org/10.4103/1596-3519.55727. PMid:18240495

27. Were E, Nyaberi Z, Buziba N. Perceptions of risk and barriers to cervical cancer screening at Moi Teaching and Referral Hospital (MTRH), Eldoret, Kenya. Afr Health Sci. 2011;11(1):58-64. PMid:21572858 English.

28. Udofia EA, Akwaowo CD, Ekanem US. Awareness, use and main source of information on preventive health examinations: a survey of childbearing women in Uyo, Nigeria. Afr $J$ Reprod Health. 2012;16(4):149-61. PMid:23444552 English.

29. Nwankwo KC, Aniebue UU, Aguwa EN, Anarado AN, Agunwah E. Knowledge attitudes and practices of cervical cancer screening among urban and rural Nigerian women: a call for education and mass screening. Eur J Cancer Care (Engl). 2011;20(3):362-7. http://dx.doi.org/10.1111/j.1365- 2354.2009.01175.x.

30. Ndikom CM, Ofi BA. Awareness, perception and factors affecting utilization of cervical cancer screening services among women in Ibadan, Nigeria: a qualitative study. Reprod Health. 2012;9(1):11. http://dx.doi. org/10.1186/1742-4755-9-11. PMid:22866676 English.

31. Teng FF, Mitchell SM, Sekikubo M, Biryabarema C, Byamugisha JK, Steinberg $\mathrm{M}$, et al. Understanding the role of embarrassment in gynaecological screening: a qualitative study from the ASPIRE cervical cancer screening project in Uganda. BMJ Open. 2014;4(4):e004783. http://dx.doi. org/10.1136/bmjopen-2014-004783. PMid:24727360

32. Nwobodo EI, Malami SA. Knowledge and practice of cervical screening among female health workers in Sokoto, North Western Nigeria. Niger Postgrad Med J. 2005;12(4):255-7. PMid:16380734 English.

33. Chigbu CO, Onyebuchi AK, Ajah LO, Onwudiwe EN. Motivations and preferences of rural Nigerian women undergoing cervical cancer screening via visual inspection with acetic acid. Int J Gynaecol Obstet. 2013;120(3):262-5. http://dx.doi. org/10.1016/j.ijgo.2012.10.011. PMid:23228820 English.

34. Poletti T, Balabanova D, Ghazaryan $\mathrm{O}$, Kamal-Yanni M, Kocharyan $\mathrm{H}$, Arakelyan K, et al. Options for scaling up community-based health insurance for rural communities in Armenia. London: London School of Hygiene and Tropical Medicine; 2007.

35. Ajayi IO, Adewole IF. Determinants of utilisation of cervical cancer screening facility in a low socio-economic setting in Nigeria. J Obstet Gynaecol. 1998;182:154-8. http://dx.doi. org/10.1080/01443619867920.

36. Bornemisza O, Ranson MK, Poletti TM, Sondorp E. Promoting health equity in conflict-affected fragile states. Soc Sci Med. 2010;70(1):808. http://dx.doi.org/10.1016/j. socscimed.2009.09.032.

37. Jacobs B, Ir P, Bigdeli M, Annear PL, Van Damme W. Addressing access barriers to health services: an analytical framework for selecting appropriate interventions in lowincome Asian countries. Health Policy Plan. 2012;27(4):288-300. http:// 
dx.doi.org/10.1093/heapol/czr038. PMid:21565939 English.

38. Shakibazadeh E, Ahmadnia E, Akbari F, Negarandeh R. Barriers and motivating factors related to cervical cancer screening. Hayat. 2008;14(3). Persian.

39. Gorter A, Ir P, Meessen B. Evidence Review, Results-Based Financing of Maternal and Newborn Health Care in Low- and Lower-middleIncome Countries. Germany: Deutsche Gesellschaft fur Internationale Zusammenarbeit. 2013. Commissioned and funded by the German Federal Ministry for Economic Cooperation and Development (BMZ) through the sector project Programme to Foster Innovation, Learning and Evidence in Health Programmes of the German Development Cooperation.

40. Lagarde M, Haines A, Palmer N. Conditional cash transfers for improving uptake of health interventions in low- and middleincome countries: a systematic review. JAMA. 2007;298(16):1900-10. http:// dx.doi.org/10.1001/jama.298.16.1900.

41. Ekman B. Community-based health insurance in low-income countries: a systematic review of the evidence. Health Policy Plan. 2004;19(5):24970. http://dx.doi.org/10.1093/heapol/ czh031. PMid:15310661

42. Lu M, Moritz S, Lorenzetti D, Sykes L, Straus S, Quan H. A systematic review of interventions to increase breast and cervical cancer screening uptake among Asian women. BMC Public Health. 2012;12(1):413. http:// dx.doi.org/10.1186/1471-2458-12-413. PMid:22676147

43. Ahmed SM, Petzold M, Kabir ZN, Tomson G. Targeted intervention for the ultra poor in rural Bangladesh: Does it make any difference in their health-seeking behaviour? Soc Sci Med. 2006;63(11):2899911. http://dx.doi.org/10.1016/j. socscimed.2006.07.024. PMid:16954049

44. Abiodun OA, Olu-Abiodun OO, Sotunsa JO, Oluwole FA. Impact of health education intervention on knowledge and perception of cervical cancer and cervical screening uptake among adult women in rural communities in Nigeria. BMC Public Health. 2014;14(1):814. http://dx.doi. org/10.1186/1471-2458-14-814. PMid:25103189 English.
45. Haines A, Sanders D, Lehmann U, Rowe AK, Lawn JE, Jan $\mathrm{S}$, et al. Achieving child survival goals: potential contribution of community health workers. Lancet. 2007;369(9579):2121-31. http://dx.doi. org/10.1016/S0140-6736(07)60325-0. PMid:17586307 English.

46. Gupta I, Joe W, Rudra S. Demand side financing in health: how far can it address the issue of low utilization in developing countries? Geneva: World Health Organization; 2010. World Health Report (2010) Background Paper, no 27.

47. Grainger C, Gorter A, Okal J, Bellows B. Lessons from sexual and reproductive health voucher program design and function: a comprehensive review. Int J Equity Health. 2014;13:33. http://dx.doi. org/10.1186/1475-9276-13-33.

48. Iliyasu Z, Abubakar IS, Aliyu MH, Galadanci HS. Cervical cancer risk perception and predictors of human papilloma virus vaccine acceptance among female university students in northern Nigeria. J Obstet Gynaecol. 2010;30(8):857-62. http://dx.doi.org/10 .3109/01443615.2010.511724.

Received: 01/07/2015

Accepted: 02/13/2015 